\title{
イオンプレーティング膜の膜厚測定に及ぼす ホローカソード効果
}

\author{
榎本祐嗣* \\ (昭和51年 9 月 1 日 受理) \\ Film Step Height Affected by Hollow Cathode Effect in Ion Plating \\ Yuji ENOMOTO \\ (Mechanical Engineering Laboratory, 12-1 Igusa 4-chome, \\ Suginami-ku, Tokyo 167) \\ (Received September 1, 1976)
}

\section{1.はじめに}

グロー放電プラズマ中で蒸着を行ら D. C イオンプレ ーティングやバイアススパッタリング法では被めっき物 体に負の高電圧が印加されている. そのため段差, 穴, 凹部など複雑な形状を有する被めっき物体の場合には， 2 次電子がその附近でトラップされやすく, 従って局所 的にプラズマ密度が増すいわゆるホローカソード効果が 生じる11。このような複雑な形状領域ではスパッ夕速度 が高くなるために蒸着膜は過㮃なエッチングを受ける.

一般に上述の蒸着方法ではガス圧力が比較的高く, 蒸着 原子の平均自由行程が小さくなるためガス散乱効果によ りつきまわりが良いとされているものの2)，ホローカソ 一ド効果は遮蔽効果と共に蒸着膜厚を不均一化する原因 となる.

一方, 光干涉, 触針, 光切断などの膜厚測定法におい ては，被めっき物をマスクして得られる被膜段差を利用 して厚みの測定を行う。この場合にもマスク端で上述の ホローカソード効果の影響は避けられないであろら。

最近 Gardos ${ }^{3}$ はバイアススパッタリング法による $\mathrm{MoS}_{2}$ 被膜の厚み測定で, マスキング角度が小さくなる につれ測定される厚みが直線的に大きくなる事を見い出 している. また正確な厚みとして，マスキング角度を $0^{\circ}$ にグラフ的に外插して求める方法を提案している。 しか し印加電圧, マスキング高さ, 遮蔽効果とホローカソー ド効果の影響の程度など尚十分でない点があり, さらに

\footnotetext{
* 機械技術研究所基嗼部（杉並区井草 4-12-1）
}

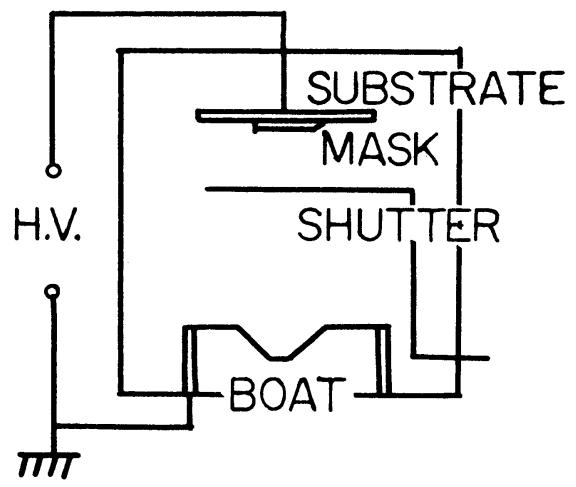

Fig. 1 Schematic of D.C. ion plating system.

詳しく検討する必要があると思われたので，D．C イオ ンプレーティング法でこのような実験を行ってみた.

\section{2. 実験装置と寸法}

Fig. 1 に実験に使用した 2 極型イオンプレーティング 装置の概略図を示す．銅基板 $(75 \times 75 \times 3 \mathrm{~m} \mathrm{~m})$ はアル ミナ㦟濁液で研摩仕上げしたのち, さらに電解研摩で鏡 面仕上げにした。 マスク（４４Ｃ銅）は Fig. $2 \mathrm{~A}$ およ びBに示す 2 通りのものを使用し，それぞれマスキング 角度の影響及びマスキング高さの影響について調べた。 タイプ A は $30 \mathrm{~mm}$ 角, 高さ $2.5 \mathrm{~mm}$ で各辺のエッヂ角度は $20^{\circ}, 45^{\circ}, 60^{\circ}, 90^{\circ}$ に加工してある。一方タイプBでは $40 \mathrm{~mm} \phi$ で高さが最大 $5.2 \mathrm{~m} \mathrm{~m}$ から最少 $0.2 \mathrm{~m} \mathrm{~m}$ となるよ うな傾斜がつけてある。

触針法（タリサーフ 4 型, 測定力 $100 \mathrm{mg}$ ) で被膜段差 


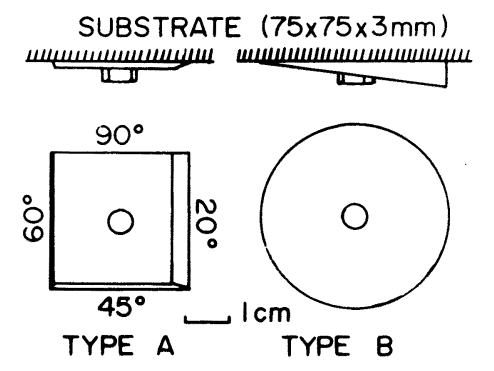

Fig. 2 Types of mask: upper; side view, lower; top view

を測定する際の，圧子の切り込み影響を最小とするため に，基板と同じ銅を蒸発材料とした。 また蒸着中に蒸発 面積が一定值を保ち (0.5 $\mathrm{cm}^{2}$ 以下)，拡がらないよう Fig. 1 に示すような傾斜のついたタングステンボートを 使用した。

基板のスパッタクリーニングをアルゴンガス圧 $1.4 \times$ $10^{-2}$ Torr, 放電電圧 $3 \mathrm{kV}$ で10分間行った後に, 約 $1.3 \mathrm{~g}$ の銅を 4 〜 6 分で蒸発し終るように一定加熱電力でイオ ンプレートした.このときのアルゴンガス圧は $1.1 \times 10^{-2}$ Torr で, 放電電圧は $0,1.5,3 \mathrm{kV}$ の 3 通りとした.

\section{3. 実験結果と考察}

放電電圧 $3 \mathrm{kV}$ においてタイプ A で基板をマスクし, 蒸 着の後マスキング角度の異なる各辺の中心附近で出来た 被膜段差を触針法で測定したときの記録例を Fig. 3 に示 した・被膜高さは Fig. 3 に示すように信号が立ち上りき

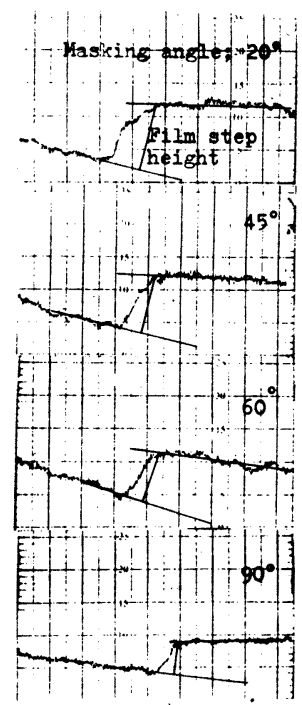

Fig. 3 Stylus traces of ion plated film step at discharge voltage of $3 \mathrm{kV}$.

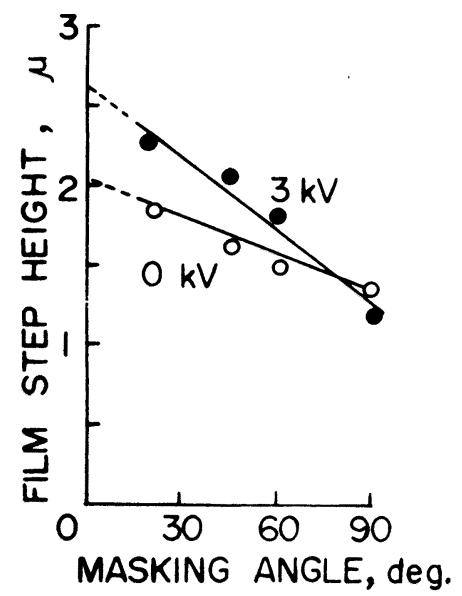

Fig. 4 Film step height as a function of masking angle: masking height $2.5 \mathrm{~mm}$.

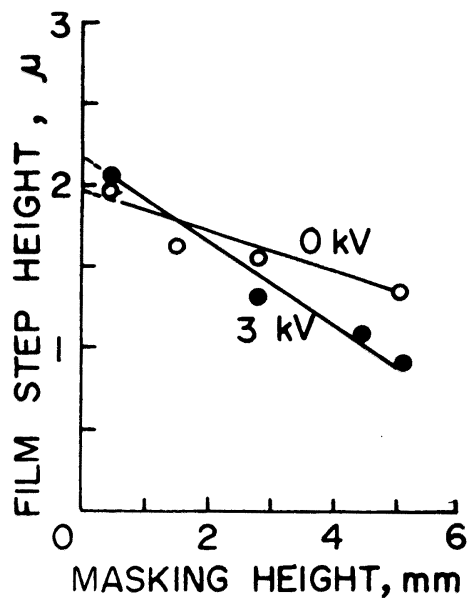

Fig. 5 Film step height as a function of masking height: masking angle $90^{\circ}$.

ったところでのベースラインから立てた垂線が被膜表面 ラインと交わる点までの距離から求めた。このようにし て各角度で数回の記録をとり,その平均值を Fig. 4 に放 電電圧 $0 \mathrm{kV}$ すなわちガス 散乱蒸着及び $3 \mathrm{kV}$ でイオン プレートしたときの被膜高さとマスキング角度の関係を 示した. いずれの場合も測定される被膜高さはマスキン グ角度の減少と共に直線的に大きくなっている．ガス散 乱蒸着の場合, これは遮蔽効果によるもので, 放電電圧 が印加されるとホーローカソード効果により上述の傾向 が強められている事が判る. 尚 $1.5 \mathrm{kV}$ での傾向を図示し なかったが傾斜の勾配は 0 と $3 \mathrm{kV}$ の中間にあった.

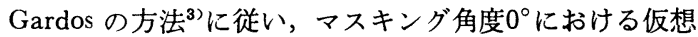


被膜高さが真の膜厚を与えるとして Fig.4 の点線で示す ような外挿を行うと $0 \mathrm{kV}$ の場合で $2.0 \mu \mathrm{m}, 3 \mathrm{kV}$ で2. 6 $\mu \mathrm{m}$ となり, それぞれの蒸着時間で割ると蒸発速度はい うれも $0.44 \mu \mathrm{m}$ 毎分となった. 放電電圧 $3 \mathrm{kV}$ の場合, マスキング角度 $90^{\circ}$ で測定される被膜厚みは外插から 求 められる值の約半分に過ぎない事は注意すべきことでは ないかと思う。

タイプBのマスクで得られた被膜高さとマスキング高 さとの関係を Fig.4 に示した.この場合もほぼ直線 的 な関係が成立しており，当然の事ながらマスキング高さ が高いとホーローカソード効果が顕著となる事が判る. 先と同様な考えに基づいて高さ $0 \mathrm{~mm}$ に外挿して求めた 仮想膜厚と高さ $0.2 \mathrm{~mm}$ における被膜高さとの差は放電

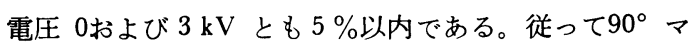

スキング角の場合には高さが $0.2 \mathrm{~mm}$ 程度であれば正確 な膜厚測定には十分であるといえよう，またそれより大 きいとマスキング角度を出来るだけ小さくしなければな らないことになる。いづれにしても段差法によるイオン プレーティング膜厚の正確な測定にはマスキング状態に 十分の注意を払わなくてはならない.

\section{〔文献〕}

1) D. M. Mattox: Development Report SLA-730619 (1973).

2) K. Matsubara et al.: Japan J. appl. Phys. Suppl. 2, Pt. 1 (1974) 455.

3) M. N. Gardos: ASLE Preprint for 30th Annu. Meet., Atlanta (1975) 1. 